\title{
Effect of processing on micronutrient content of chips produced from some plantain and banana hybrids
}

Tajudeen Adebayo AdenIJI*, Abdou TENKouANO

International Institute of Tropical Agriculture, PMB 5320, Oyo Road, Ibadan, Nigeria,

tiradeniji@yahoo.com
${ }^{*}$ Correspondence and reprints

Received 30 January 2007 Accepted 9 July 2007

Fruits, 2007, vol. 62, p. 345-352 (C) 2007 Cirad/EDP Sciences All rights reserved DOI: $10.1051 /$ fruits:2007031 www.fruits-journal.org

RESUMEN ESPAÑOL, p. 352

\section{Effect of processing on micronutrient content of chips produced from some plantain and banana hybrids.}

\begin{abstract}
Introduction. Chips or crisps are the most important foods usually fried; they are presented in the form of thin discs (chips) or sometimes in the form of sticks (French fries). Materials and methods. Chips were prepared starting from pulp samples resulting from five hybrids of plantain and banana newly released in Nigeria and from a local cultivar used as reference. The iron, zinc and pro-vitamin A contents were investigated in the chips to unveil their micronutrient content. Results and discussion. The results showed that there was no significant difference $(p<0.05)$ in the iron content of the chips produced from the new plantain and banana hybrids, while a significant difference $(p<0.05)$ existed in both zinc and total carotenoid contents of the hybrids. Chips made from BITA 3, a hybrid cooking banana, could contribute 2.61 retinol equivalent $(\mathrm{RE})^{\mathrm{e}}\left[1(\mathrm{RE})^{\mathrm{e}}=6 \mu \mathrm{g} \beta\right.$-carotene (precursor of vitamin A)] daily, if a small packet of chips ( $45 \mathrm{~g}$ ) is consumed, based on the Recommended Daily Dietary Allowance. A 45-g packet of chips made from PITA 26 can contribute 14.6\% and $20.1 \%$ of the daily requirements of zinc per day, and $30.1 \%$ and $22.3 \%$ of the requirements of iron per day, for a man and a woman, respectively. Conclusions. The new plantain and banana hybrids may therefore significantly participate in a food strategy aiming at combating the lack of micronutrients in the sub-Saharan African diet.
\end{abstract}

Nigeria / Musa / fruit pulps / frying / chemical composition / iron / zinc / carotenoids / retinol

\section{Effet du traitement thermique sur la teneur en micronutriments de croustilles produites avec certains hybrides de plantain et de banane.}

Résumé - Introduction. Les chips ou les frites font partie des aliments frits les plus importants ; ils se présentent sous forme de rondelles minces (chips) ou sous forme bâtonnets (frites). Matériel et méthodes. Des chips ont été préparées à partir d'échantillons de pulpe issue de cinq hybrides de plantains et de bananes nouvellement diffusés au Nigéria et d'un cultivar local utilisé comme témoin. Les teneurs en fer, zinc et provitamine A du produit transformé ont été étudiées pour évaluer leur contenu en micronutriments. Résultats et discussion. Les résultats ont montré qu'il n'y avait aucune différence significative $(p<0,05)$ entre les teneurs en fer des chips issues des nouveaux hybrides de plantains et bananes, tandis que des différences significatives $(p<0,05)$ existaient pour les teneurs en zinc et en carotenoïdes totaux de ces hybrides. En se basant sur l'allocation alimentaire quotidienne recommandée (AAQR), les chips de BITA 3, une banane à cuire hybride, pourraient apporter quotidiennement 2,61 équivalents rétinol $(\mathrm{ER})^{\mathrm{e}}\left[1(\mathrm{ER})^{\mathrm{e}}=6 \mu \mathrm{g} \beta\right.$-carotène (précurseur de la vitamine A)], si un petit paquet de chips ( $45 \mathrm{~g}$ ) était consommé chaque jour. En se basant sur l'AAQR, un paquet de $45 \mathrm{~g}$ de chips de PITA 26 pourrait apporter 14,6\% et 20,1\% des besoins journaliers en zinc, et $30,1 \%$ et $22,3 \%$ des besoins en fer, pour un homme et une femme adultes, respectivement. Conclusions. Les nouveaux hybrides de plantains et de bananes peuvent donc participer significativement à une stratégie alimentaire visant à combattre le manque de micronutriments dans l'alimentation de l'Afrique subsaharienne.

Nigéria / Musa / pulpe de fruits / friture / composition chimique / fer / zinc / caroténoïde / rétinol 


\section{Introduction}

The annual world production of plantain and banana is estimated at 75 Mt [1]. In Nigeria, plantain production was estimated at about $2.11 \mathrm{MT}$ in 2004 [2]. Plantain and banana are grown in some 120 countries [3]; they are major carbohydrate staples of the local populations in the developing world. In Nigeria, plantain and banana are eaten in many forms, including chips, dodo, roasted, boiled, porridge and flour $[4,5]$.

Chips are ready-to-eat food; they are one of the most popular fried products worldwide, especially the internationally traded potato chips [6]. They are conventionally produced by deep-frying of pulp slices in heated vegetable oil, and can be preserved for a long time given adequate packaging and storage facilities. Several studies have been conducted on the use of Musa species fruits for chip-making [7-12].

The World Bank [13] reported vitamin A deficiency (VAD) as the most common form of global malnutrition after protein deficiency. Davey et al. [14] reported that VAD is a leading cause of early childhood death and a major risk factor for pregnant women in Africa, Micronesia and other parts of the world. In parts of Asia, Africa and Latin America, vitamin A deficiency occurs in millions of children [15]; new Musa hybrids may be an important source of provitamin A for the people of those regions.

In Southeast Nigeria, $50 \%$ of children and $61 \%$ of women suffer from chronic anaemia, due to iron deficiency [16], whose symptoms include learning disability, mental retardation, poor physical development and reduced ability to fight infectious diseases, ultimately leading to premature death. Zinc deficiency is responsible for growth failure, hypogonadism and anaemia [17]. Preformed vitamin A, whose official chemical name is retinol [18], is found only in foods of animal origin. Carotenoids form one of the most important classes of plant pigments and play an important role in defining the quality parameters of fruit and vegetables [19]. They are the primary source of vitamin A for most people living in developing countries [20], where vitamin A deficiencies are still prev- alent [21]. The Institute of Medicine, National Academy of Sciences, also reported that carotenoids have a variety of actions that are related to the decreased risk of some degenerative diseases [22].

Deep-fried plantain and banana chips may potentially be used in intervention programs to combat micronutrient deficiencies, by virtue of their iron, zinc and total carotenoid content. The fat content of chips may increase the carotenoid bioavailability [23], though it may also reduce product shelf life due to lipid oxidation [24]. Davidson et al. [18] also reported that retinol is stable to heat at ordinary cooking temperatures, but liable to oxidation and destruction if the fats in the product that contained it turned rancid, and could also be destroyed by exposure to light.

There is increasing interest in developing disease-resistant, high-yielding genotypes of plant species which are rich sources of iron, zinc and provitamin A carotenoids (pVACs) [25-27]. Successful genetic manipulation of carotenogenesis has been achieved in rice [19] and canola (rapeseed, Brassica napus) [19, 28]. Intervention studies undertaken using $\beta$-carotene (precursor of vitamin A) supplements rather than using foods with enhanced carotenoid levels resulted in no potential benefit, while food supplements and fortified products are beyond the reach of many households in the developing countries. The Consultative Group on International Agricultural Research (CGIAR) has launched a nutritional breeding program aimed at improving the micronutrient (including iron, zinc and pro-vitamin A) status of various agricultural crops. The International Institute of Tropical Agriculture (IITA), a key member of CGIAR, is currently working in this direction on its mandate crops, including plantain and banana, cassava and yam. In the genus Musa, a great deal of diversity exists, and the occurrence of plantain and banana varieties with naturally orange-colored fruit pulp is an indication that these varieties could be an important source of dietary pVACs. The mineral profiles of Musa species fruit have been widely reported [29-31]. The demand for plantain and banana chips in Nigeria is increasing, in spite of fragmentary reports 
on their nutritional potential. Our research was therefore conducted to determine some major micronutrients in chips made from new plantain and banana hybrids being currently disseminated in Nigeria, and many parts of West and Central Africa (WCA), and East and Southern Africa (ESA), to unveil their nutritional value.

\section{Materials and methods}

Five matured bunches of new Musa hybrids (10 months old) were investigated:

- three plantain hybrids developed at the IITA, Nigeria, named with the prefix PITA (Plantain International Institute of Tropical Agriculture): PITA 14, PITA 17 and PITA 26,

- two cooking banana hybrids: one hybrid developed at the IITA, Nigeria, named with the prefix BITA (Banana International Institute of Tropical Agriculture): BITA 3; and one hybrid developed at the Fundacion Hondureña De Investigación Agricola (FHIA): FHIA 25.

Moreover, a mature bunch of a local plantain (12 months old), Agbagba, was studied as reference.

Samples were obtained from the experimental station of the International Institute of Tropical Agriculture (IITA), High Rainfall Station, Onne, located at lat. $04^{\circ} 43^{\prime} \mathrm{N}$, Long. $07^{\circ} 01^{\prime} \mathrm{E}$ and $10 \mathrm{~m}$ alt., near Port Harcourt, Nigeria.

\subsection{Preparation of chips}

Deep-fried chips were prepared according to the procedures described by Adeniji [11]. Bunches were harvested at the green stage and de-handed prior to de-fingering of representative fruits from the second hand from the proximal end of the bunch, according to Baiyeri and Ortiz's [32] recommendation. Fruits were washed to remove dirt and latex and then carefully hand-peeled with the aid of a stainless steel kitchen knife; the resultant pulps were immersed in water to prevent browning during the peeling process. Pulps were placed into a clean bowl and seasoned with salt. Fruits were sliced disc- wise $(0.15 \mathrm{~cm})$ with the aid of a Plantain Slicer, SF923-1, CEE Square Ltd., Leawood Blvd, Houston, Texas, USA, into a preheated vegetable oil at $190{ }^{\circ} \mathrm{C}$ with constant stirring for $5 \mathrm{~min}$ until crisp. Chips were placed into an aluminum sieve and properly drained to remove excess oil, then they were allowed to cool at room temperature.

\subsection{Determination of iron and zinc}

Iron and zinc analysis was performed in triplicate using the procedure described by Allen et al. [33]. The analytical procedures used for sample treatment for Atomic Absorption Spectrophotometry (AAS) analysis are as follows: Chips were milked with the aid of stainless Kenwood Chef Warning Blender, model KM001 (0067078) series. A one-g sample was weighed into a Pyrex glass conical flask. Ten $\mathrm{mL}$ of concentrated nitric acid was introduced into the flask with a straight pipette. Five $\mathrm{mL}$ of perchloric acid was also added. The mixture was heated on an electro-thermal heater for about $20 \mathrm{~min}$ until a clear digest was obtained. The digest was cooled to room temperature and diluted to $50 \mathrm{~mL}$ with distilled water. The diluent was filtered into a plastic vial for AAS analysis.

\subsection{Determination of total carotenoids}

The total carotenoid content of the sample was performed spectrophotometrically in triplicate using the method described by Rodriguez-Amaya [34].

For the sample preparation, about $5 \mathrm{~g}$ of plantain or banana chips were weighed into a beaker, then transferred into a mortar; $3 \mathrm{~g}$ of Hyflosupercel (Celite) were added. The mixture was ground with $50 \mathrm{~mL}$ of cold acetone (acetone left in the refrigerator for about $2 \mathrm{~h}$ ). It was then filtered with suction through a Buchner funnel with filter paper. The mortar, pestle, funnel and residue were washed with a small amount of acetone, and this was received in the suction flask through the funnel, ensuring that the residue and washings were devoid of color. About $40 \mathrm{~mL}$ of petroleum ether was measured into a 500-mL separatory funnel and the acetone extract was added. About 
Table I.

Micronutrient content $\left(\mu \mathrm{g} \cdot \mathrm{g}^{-1}\right)$ of chips produced from plantain and banana hybrids (Nigeria).

\begin{tabular}{lcccc}
\hline Cultivar name & Origin & Iron content & Zinc content & Total carotenoid content \\
\hline PITA 14 & Hybrid & $41.4^{\mathrm{a}}$ & $19.8^{\mathrm{a}, \mathrm{b}}$ & $0.21^{\mathrm{c}}$ \\
PITA 17 & Hybrid & $26.5^{\mathrm{a}}$ & $12.2^{\mathrm{b}}$ & $0.28^{\mathrm{b}}$ \\
PITA 26 & Hybrid & $40.1^{\mathrm{a}}$ & $30.4^{\mathrm{a}}$ & $0.24^{\mathrm{c}}$ \\
BITA 3 & Hybrid & $32.9^{\mathrm{a}}$ & $23.5^{\mathrm{a}, \mathrm{b}}$ & $0.35^{\mathrm{a}}$ \\
FHIA 25 & Hybrid & $23.8^{\mathrm{a}}$ & $9.5^{\mathrm{b}}$ & $0.30^{\mathrm{b}}$ \\
Agbagba & Landrace & $40.6^{\mathrm{a}}$ & $15.0^{\mathrm{a}, \mathrm{b}}$ & $0.31^{\mathrm{b}}$ \\
\multicolumn{2}{l}{ Values in the same column with different letters are significantly different at $p<0.05}$.
\end{tabular}

$300 \mathrm{~mL}$ of distilled water were added slowly and allowed to flow along the walls of the funnel. Shaking was avoided to prevent formation of an emulsion. The two phases were allowed to separate and the lower aqueous phase discarded. The upper phase left in the funnel was washed 3-4 times with $200 \mathrm{~mL}$ each time to remove residual acetone. Care was taken to discard the lower phase as completely as possible during the last washing, without discarding part of the upper phase. The petroleum ether phase was collected in a 50-mL volumetric flask, making the solution pass through a small funnel containing about $15 \mathrm{~g}$ of anhydrous sodium sulfate to remove residual water. In the process, a glass wool plug was used to hold the sodium sulfate. The separatory funnel was washed with petroleum ether and this was collected in the volumetric flask, passing through the funnel with sodium sulfate.

The sample was made up to volume and the absorbance read at $450 \mathrm{~nm}$; the total carotenoid was calculated with the following formula: total carotenoid $\left(\mathrm{g}^{\mathrm{g}} \mathrm{g}^{-1}\right)=[\mathrm{A} \times \mathrm{vol}-$ ume $\left.(\mathrm{mL}) \times 10^{4}\right] /\left[\mathrm{A}_{1 \mathrm{~cm}}{ }^{1 \%} \times\right.$ sample weight (g)], where $\mathrm{A}=$ absorbance; volume $=$ total volume of extract $=50 \mathrm{~mL} ; \quad \mathrm{A}_{1 \mathrm{~cm}}{ }^{1 \%}=$ absorption coefficient of $\beta$-carotene in petroleum ether (2592).

\subsection{Estimation of retinol equivalent}

The retinol equivalent $(\mathrm{RE})^{\mathrm{e}}$ was calculated from the total carotenoids obtained in plantain and banana chips, based on the report of Davidson et al. [18], which revealed that $6 \mu \mathrm{g}$ of $\beta$-carotene has the biological activity of $1 \mu \mathrm{g}$ of retinol, and most of this difference is due to poor absorption of carotene. The percentage daily contribution of both iron and zinc were estimated using the Recommended Daily Dietary Allowances (RDDA) of the Institute of Medicine, National Academy of Sciences [22].

\subsection{Data analyses}

The data generated in triplicate were analyzed using the Statistical Analysis Systems [35] software package. Significance of treatment means was tested at the $5 \%$ probability level using Duncan's New Multiple Range Test.

\section{Results and discussion}

The results of the micronutrient composition of chips produced from new plantain and banana hybrids showed that there was no significant difference $(p>0.05)$ in the iron content of the chips made from different cultivars (table I). However, the zinc content of PITA 26 chips differed significantly $(p<0.05)$ from those of PITA 17 and FHIA 25. The iron and zinc contents of the chips studied in our experiment was lower than those reported earlier in plantain [31] and sweet potato varieties [36]. Frying and boiling has been reported to reduce the iron, zinc and copper contents of plantain [31]. 


\section{Table II.}

Estimated percentage daily contribution of iron and zinc from a small packet $(45 \mathrm{~g})$ of plantain and banana hybrid chips based on Recommended Daily Dietary Allowances (RDDA) [22] (Nigeria).

\begin{tabular}{lccccc} 
Cultivar & Origin & \multicolumn{2}{c}{ \% daily contribution of iron } & \multicolumn{2}{c}{ \% daily contribution of zinc $^{2}$} \\
\cline { 3 - 5 } & & Adult males & Adult females & Adult males & Adult females \\
\hline PITA 14 & Hybrid & 31.1 & 23.0 & 9.5 & 13.1 \\
PITA 17 & Hybrid & 19.9 & 14.7 & 5.8 & 8.1 \\
PITA 26 & Hybrid & 30.1 & 22.3 & 14.6 & 20.1 \\
BITA 3 & Hybrid & 24.7 & 18.3 & 11.3 & 15.6 \\
FHIA 25 & Hybrid & 17.9 & 13.2 & 4.3 & 6.3 \\
Agbagba & Landrace & 30.5 & 22.6 & 7.2 & 9.9 \\
\hline &
\end{tabular}

\section{Table III.}

Comparison of plantain and banana hybrid chips' content for their contribution to meeting daily vitamin A requirements, based on the Recommended Daily Dietary Allowances [22].

\begin{tabular}{lccc} 
Cultivar & $\begin{array}{c}\text { Total carotenoids } \\
\left(\mu \mathrm{g} \cdot \mathrm{g}^{-1}\right)\end{array}$ & $\begin{array}{c}\text { Retinol equivalent } \\
(\mathrm{RE})^{\mathrm{e}}\end{array}$ & $\begin{array}{c}(\mathrm{RE})^{\mathrm{e}} \\
\text { for a 45-g packet of chips consumed daily }\end{array}$ \\
\hline PITA 14 & 0.21 & 0.035 & 1.575 \\
PITA 17 & 0.28 & 0.047 & 2.115 \\
PITA 26 & 0.24 & 0.040 & 1.800 \\
BITA 3 & 0.35 & 0.058 & 2.610 \\
FHIA 25 & 0.30 & 0.050 & 2.250 \\
AGBAGBA & 0.31 & 0.052 & 2.340
\end{tabular}

The iron content of plantain is $100 \%$ utilizable for human consumption when compared with other foods [37]. The estimated daily contribution of iron from a small packet of $45 \mathrm{~g}$ of chips made from PITA 14 are $31.1 \%$ and $23.0 \%$ of the RDDA for an adult male and female, respectively, while, if the same quantity of chips is consumed, PITA 26 can contribute $14.6 \%$ and $20.1 \%$ zinc of the RDDA daily for an adult male and female, respectively (table II).

The total carotenoid content of BITA 3 chips differed significantly $(p<0.05)$ from those of other cultivars (table III). Also, Agbagba, FHIA 25 and PITA 17 chips were significantly different from PITA 14 and PITA 26 in total carotenoid content.

With reference to our results, chips made from BITA 3 can contribute 2.61 retinol equivalent $(\mathrm{RE})^{\mathrm{e}}$ daily, if a small packet of chips (45 g) is consumed, based on the RDDA. A small packet of plantain and banana chips sold in Nigeria usually weighs between (35 and 45) g [9]. Since plantain chips are snacks, they can be consumed in between meals as much as desired, which 
could make provision for a substantial amount of micronutrients in the diet. The vitamin A content of Cavendish banana is $60 \mathrm{~g} \cdot \mathrm{g}^{-1}$ of retinol equivalent per $\mathrm{kg}$ [38], which is higher than the present value obtained in plantain and banana chips. The carotenoid content of an edible portion of banana fruit includes $0-37 \mu \mathrm{g} \cdot 100 \mathrm{~g}^{-1}$ lutein, $0-157 \mu \mathrm{g} \cdot 100 \mathrm{~g}^{-1} \alpha$-carotene and 0 $92 \mu \mathrm{g} \cdot 100 \mathrm{~g}^{-1} \beta$-carotene [19]. Deep-frying, baking and pickling result in substantial losses of pVACs [39]. Freezing (especially quick freezing), however, preserves pVACs, but long thawing is detrimental [39, 40]

The dependence on plantain and banana consumption by both rural and urban populations in sub-Saharan Africa and their derived food products are strong indications that Musa species fruit are an important source of dietary minerals and vitamins [14]. In developed countries, $70-90 \%$ of carotenoid intake are derived from fruit and vegetables, and provide about $25-35 \%$ of the total retinol intake, whereas, in developing countries, this contribution can be as much as $82 \%$ [39]. This strongly suggests that there is real potential for improving human nutritional status and achieving long-term population health benefits without enforcing a change in dietary eating habits.

\section{Conclusion}

In spite of frying of fresh pulp slices from new Musa hybrids at high temperatures, the levels of iron, zinc and total carotenoid found in the resultant chips are capable of making a substantial contribution to recommended daily dietary allowances. Our study may provide information in support of a global effort in the elimination of micronutrient malnutrition in developing countries. New Musa hybrids may be used as a substitute for local plantain in food processing. One of the plantain hybrids used in this study (PITA 26) was rejected by some farmers during the first phase of the IITA hybrid delivery project (2000-2003) due to lack of nutritional information and processing options. Looking at data generated in the present study, PITA 26 is comparable with other varieties in micronutrient content. Con- sumption of chips made from the new hybrids may increase the intake of iron, zinc and vitamin $\mathrm{A}$ and, therefore, reduce nutritional disorders associated with these micronutrient deficiencies. Our data therefore suggest that new plantain and banana may be considered suitable for chips and other value-added products.

\section{References}

[1] John P., Marchal J., Ripening and biochemistry of the fruit, in: Gowen S.R. (Ed.), Bananas and Plantains, Chapman and Hall, 2-6 Boundary Row, London SE1 8HN, UK, 1995, 434-467.

[2] Anon., Production yearbook for 2005, FAOSTAT Data, Food and Agriculture Organisation of the United Nations, Rome, Italy, 2005.

[3] Olorunda A.O., Recent advances in postharvest technologies of banana and plantain in Africa, in: Craenen K., Ortiz R., Karamura E.B., Vuylsteke D.R. (Eds.), Proc. 1st int. conf. on banana and plantain for Africa, Kampala, Uganda, 14-18 Oct., 1996, Int. Soc. Hortic. Sci. (ISHS), Acta Hortic. 540 (2000) 517-527.

[4] Agbor A.N., Plantain and banana project in Cross River State, in: Ortiz R., Akoroda M.O. (Eds.), Plantain and banana: production and research in West and Central Africa, Proc. Reg. Workshop held at High Rainfall Station, Onne, Rivers State, Nigeria, Int. Inst. Trop. Agric. (IITA), Ibadan, Nigeria, 1996, 59-61.

[5] Echibiri T.O., Plantain and banana production in Imo State, in: Ortiz R., Akoroda M.O. (Eds.), Plantain and banana: production and research in West and Central Africa, Proc. Reg. Workshop held at High Rainfall Station, Onne, Rivers State, Nigeria, Int. Inst. Trop. Agric. (IITA), Ibadan, Nigeria, 1996, 61-62.

[6] Costa R.M., Oliveira F.A.R., Boutcheva G., Structural changes and shrinkage of potato during frying, Int. J. Food Sci. Technol. 36 (1) (2001).

[7] Ferris R., Shaun B., Adeniji T.A., Chukwu U., Akalumhe Y.O., Vuylsteke D., Ortiz R., Postharvest quality of plantains and cooking bananas, in: Ortiz R., Akoroda M.O. (Eds.), Plantain and banana: production and research in West and Central Africa, Proc. Reg. Workshop held at High Rainfall Station, Onne, Rivers State, Nigeria, Int. Inst. Trop. Agric. (IITA), Ibadan, Nigeria, 1996, pp. 15-22. 
[8] Ogazi P.O., Plantain: production, processing and utilisation, Paman Assoc. Ltd., Imo State, Nigeria, 1996, 305 p.

[9] Adeniji T.A., Ferris R.S.B., Chukwu U., Ubi A., Amos N., Enhancing utilisation of cooking banana in rural areas of southeastern Nigeria, in: Adejoro M.A., Aiyelaagbe I.O.O. (Eds.), Proc. 15th Annu. Conf. Hortic. Soc. Nigeria, Natl. Hortic. Res. Inst., Ibadan, Nigeria, 8-11 April, 1997, Hortic. Soc. Nigeria, Ibadan, Nigeria, 1997, pp. 214-217.

[10] Yomeni M.O., Njoukam J., Tchango Tchango J., Influence of the stage of ripeness of plantains and some cooking bananas on the sensory and physico-chemical characteristics of processed products, J. Sci. Food Agric. 84 (2004) 1069-1077.

[11] Adeniji T.A., The effect of fluorescent light and packaging materials on the shelf life of plantain and banana chips during storage, Afr. J. Appl. Zool. Environ. Biol. 7 (2005) 19-22.

[12] Dzomeku B.M., Osei-Owusu M., Ankomah A.A., Akyeampong E., Darkey S.K., Sensory evaluation of some cooking bananas in Ghana, J. Appl. Sci. 6 (4) (2006) 835-837.

[13] Anon., World development report 1993: investing in health, World Bank, Oxford Univ. Press, New York, USA, 1993.

[14] Davey M.W., Keulemans J., Swennen R., Method for the efficient quantification of fruit provitamin A contents, J. Chromatogr. A 1136 (2006) 176-184.

[15] Sommer A., New imperatives for an old vitamin (A), J. Nutr. 119 (1989) 96-100.

[16] Anon., The nutritional status of women and children in Nigeria, NtI. Plan. Comm., FGN/ UNICEF, Lagos and UNICEF Ctry. Off., Lagos, Nigeria, 1994.

[17] Ihekoronye A.I., Ngoddy P.O., integrated food science and technology for the tropics, Macmillan Publ. Ltd., London and Basingstoke, UK, 1985, 386 p.

[18] Davidson S., Passmore R., Brock J.F., Truswell A.S., Human nutrition and dietetics, Sixth ed., Longman Group Ltd., London and New York, USA, 1975.

[19] Van den Berg H., Faulks R., Granado H.F., Hirschberg J., Olmedilla B., Sandmann G., Southon S., Stahl W., Review: the potential for the improvement of carotenoid levels in foods and the likely systemic effects, J. Sci. Food Agric. 80 (2000) 880-912.
[20] Boileau T.W.M., Moore A.C., Erdman J.W. Jr., Carotenoids and vitamin $A$, in: Antioxidant status, diet, nutrition, and health, Papas A.M. (Ed.), CRC Press, Boca Raton, Fla, USA, 1999 pp. 133-158.

[21] Chakravarty I., Food based strategies to control vitamin A deficiency, Food Nut. Bull. 21 (2000) 135-143.

[22] Anon., Dietary Reference Intakes (DRIs): estimated average requirements for groups, Food Nutr. Board, Inst. Med., Ntl. Acad. Sci., Ntl. Acad. Press, Washington DC, USA, 2002.

[23] Jalal F., Nesheim M.C., Agus Z., Sanjur D., Habicht J.P., Serum retinol concentrations in children are affected by food sources of $\beta$ carotene, fat intake, and antihelmintic drug treatment, Am. J. Clin. Nutr. 68 (1998) 623629.

[24] Min D.B., Schweizer D.Q., Lipid oxidation in potato chips, J. Am. Oil Chem. Soc. 60 (1983) 1662-1665.

[25] Malaisse F., Parent G., Edible wild vegetable products in the Zambezian woodland area. A nutritional and ecological approach, Ecol. Food Nutr. 18 (1985) 43-82.

[26] Becker B., Wild plants for human nutrition in the Sahelian zone, J. Arid Environ. 11 (1986) 61-64.

[27] Kim S.H., Oh S.-Y., Cultural and nutritional aspects of traditional Korean diet, World Rev. Nutr. Diet. 79 (1996) 109-132.

[28] Shewmaker C.K., Sheehy J.A., Daley M., Colburn S., Ke D.Y., Seed-specific overexpression of phytoene synthase: increase in carotenoids and other metabolic effects, Plant J. 20 (1999) 401-412.

[29] Ketiku A.O., Chemical composition of unripe (green) and ripe plantain (Musa paradisiaca), J. Sci. Food Agric. 24 (1973) 703-707.

[30] Izonfuo W.-A.L., Omuaru V.O.T., Effect of ripening on the chemical composition of plantain peels and pulps (Musa paradisiaca), J. Sci. Food Agric. 45 (1988) 333-336.

[31] Ahenkora K., Kyei M.A., Marfo E.K., Banful B., Nutritional composition of False Horn Apantu pa plantain during ripening and processing, Afr. Crop Sci. J. 4 (2) (1996) 243247.

[32] Baiyeri K.P., Ortiz R., Agronomic evaluation of plantain and other triploid Musa, in: Craenen K., Ortiz R., Karamura E.B., Vuylsteke D.R. (Eds.), Proc. 1st Int. Conf. on 
banana and plantain for Africa, Kampala, Uganda, 14-18 Oct., 1996, Int. Soc. Hortic. Sci. (ISHS), Acta Hortic. 540 (2000) 125-135.

[33] Allen S.E., Grimshaw H.M, Parkinson J.A. Quarmby C., Chemical analysis of ecological materials, Allen S.E. (Ed.), Blackwell Sci. Publ., Oxford London, UK, Edinburgh, Melbourne, Aust., 1984, $565 \mathrm{p}$.

[34] Rodriguez-Amaya D.B., A guide to carotenoid analysis in foods, ILSI Press, Washington DC, USA, 1999.

[35] Anon., SAS users guide, Release 6.12 Ed. Stat. Anal. Syst. Inst. Inc., Cary, North Carolina, USA, 1996.

[36] Onuh J.O., Akpapunam M.A., Iwe M.O., Comparative studies of the physico-chemical properties of two local varieties of sweet potato flours, Niger. Food J. 2 (2004) 141146.

[37] Loeseck W.H., Bananas, vol. 1, 2nd ed., Intersci. Publ., New York, USA, 1950, 120 p.

[38] Paul A.A., Southgate D.A.T., The composition of foods, 4th ed., McCance, Widdowson/HMSO, London, UK, 1978.

[39] Rodriguez-Amaya D.B., Carotenoids and food preparation: the retention of provitamin a carotenoids in prepared, processed and stored foods, USAID, OMNI Project, United States Agency Int. Dev., Oppor. Micronutr. Interv., Arlington, USA, 1997.

[40] Craft N.E., Wise S.A., Individual carotenoid content of SRM 1548 total diet and influence of storage temperature, lyophilization and irradiation on dietary carotenoids, J. Agric. Food Chem. 41 (1993) 208-213.

\section{Efecto del tratamiento térmico en el contenido de micronutrientes de fritos crujientes producidos con ciertos híbridos de plátano y de banano.}

Resumen - Introducción. Las patatas chips o las patatas fritas forman pate de los alimentos fritos más importantes. Se presentan en forma de finas rodajitas (chips) o con forma de palitos (patatas fritas). Material y métodos. Se prepararon chips a partir de muestras de pulpa procedente de cinco híbridos de plátanos y de bananos nuevamente difundidos en Nigeria, así como de un cultivar local empleado como ensayo. Se estudiaron los contenidos de hierro, zinc y de provitamina A del producto transformado con el fin de evaluar su contenido en micronutrientes. Resultados y discusión. Los resultados mostraron que no existía ninguna diferencia significativa $(p<0.05)$ entre los contenidos de hierro de los chips derivados de los nuevos híbridos de plátanos y de bananos, mientras que sí existían diferencias significativas $(p<0.05)$ en el contenido de zinc y de carotenoides totales de estos híbridos. Basándose en el aporte diario recomendado (A.D.R.), los chips de BITA 3, un banano para cocinar híbrido, podrían aportar diariamente 2,61 de equivalente de retinol $(\mathrm{RE})^{\mathrm{e}}\left[1(\mathrm{RE})^{\mathrm{e}}=\right.$ $6 \mu \mathrm{g}$ caroteno (precursor de la vitamina A)], si se consumiese al día un pequeño envase de chips ( 45 g). Basándose en el A.D.R., un envase de 45 g de chips de PITA 26 podría aportar $14,6 \%$ y $20,1 \%$ de las necesidades diarias de zinc, y $30,1 \%$ y $22,3 \%$ de las necesidades de hierro, en el hombre y en la mujer, respectivamente. Conclusiones. Con todo, los nuevos híbridos de plantanos y de bananos pueden participar significativamente en una estrategia alimentaria cuyo objetivo es el de combatir la falta de micronutrientes en la alimentación del África subsahariana.

Nigeria / Musa / pulpa de frutas / fritura / composición quimica / hierro / cinc / carotinoides / retinol 